\title{
Embracing the Divine: Devotional Zeal and Mrstical “Humanation” in Rembrandt's ANNUNCIATION SKETCH
}

\author{
Catherine M. Nutting, University of Victoria
}

\begin{abstract}
Rembrandt's $17^{\text {th }}$-century sketches of radical religious transformation illuminate the inner workings of spiritual conviction and reveal the religious tone of Rembrandt's society. But they also privilege psychology over narrative, and use emotionally charged gestures to elucidate human responses to divine presence. In particular, Rembrandt develops the symbol of the divine touch, which I argue parallels the $17^{\text {th }}$-century Dutch absorption in debates about the workings of God's grace. The symbolic physical closeness that characterises Rembrandt's Old and New Testament subjects is grounded in the Reformation emphasis on personally knowing a magnanimous God, which is in turn rooted in concepts of the mystical marriage between God and "saved humanity," themes that underlie Rembrandt's unusual Annunciation sketch.
\end{abstract}

$\mathrm{R}$ embrandt van Rijn's sketch, the Annunciation, ca. 1635, is steeped in the $17^{\text {th }}$-century notion of God's active role personally knowing God. ${ }^{1}$ The sketch's visual motifs of spiritual

1 Rembrandt van Rijn (1606-1669), Annunciation, 1635, 14.4x12.4cm, brown ink and white gouache, Besançon Museum of Fine Arts and Archaeology, inv. D.2618. Also see Otto Benesch, The Drawings of Rembrandt: First Complete Edition in Six Volumes, Vol. I. (London: Phaidon, 1973), Fig. 116. Because space does not permit me to show all the images 
closeness and of divine touch stand in contrast with earlier theological and artistic imagery of humanity separated by the wall of the senses from a God who sat in distant judgment. Rembrandt's recurring interest in sketching a metaphorical divine/human embrace betrays the symbolic gesture's ancestry in the medieval mystical tradition that influenced $17^{\text {th }}$-century religion, a tradition of impassioned love for God that is typified in this poetic Early Modern example:

"Ah! Chosen Love I long for thee...

But when Thou shalt command,

Then shall I be released from self!"

"Oh love most loveable ...

All the while I waited for thee,

I held thee in My arms."2

Rembrandt's portrayal of the Annunciation and other divine/human embraces mirrors $17^{\text {th }}$-century concerns about the concept of grace, and its roots in the mystical emphasis on individual connections with God: for Early Modern viewers, grace rendered God ever-present while the mystical tradition normalized physical responses to religious experiences. $^{3}$ My interest in this correlation between concepts of Reformation grace and mystical union privileges Rembrandt's

I discuss, I have footnoted textual sources for the sketches. There is debate about the authenticity of Rembrandt's art, and research into his oeuvre has resulted in many reattributions. However, the head of the Rembrandt Research Project, a research consortium (1968-2011) tasked with studying Rembrandt's art, cautions that distinguishing between Rembrandt's and his students' work may be anachronistic by Early Modern standards. Ernst van de Wetering, "The Question of Authenticity: an Anachronism?" in ed. G. Cavalli-Bjorkman, Rembrandt and His Pupils. Papers Given at a Symposium in the Nationalmuseum Stockholm, 1992. (Stockholm, 1993), 9-13; Ernst van de Wetering, ed. A Corpus of Rembrandt Paintings: Stichting Foundation Rembrandt Research Project. Vols 1-5 (The Hague: Nijhoff, 1982).

2 Mechtild of Magdeburg, (c. 1207-c. 1285) in George Scheper, The Spiritual Marriage: The Exegetical History and Literary Impact of the Song of Songs on the Middle Ages. (Princeton: Princeton University Press, 1971), 975.

3 "The experience of an inner cross of humility and obedience foreshadowed Reformation sola gratia insights. (...) By internalizing and individualizing all relations with God, the mystics became precursors to Luther's personalized approach..." Werner O. Packull, Mysticism and the Early South GermanAustrian Anabaptist Movement. (Kitchener, Ont.: Herald Press, 1977), 25. 
sketches over his paintings. I identify sketches that illustrate the conflation of narrative time with symbolic meaning, and discuss how these drawings explore spiritual transformation and the Reformation concept of God's active role in humanity's salvation. Specifically, Rembrandt's Annunciation sketch reveals the Reformation concept of justification by grace and the vestiges of its medieval mystical roots.

The emotionally impactful style of Rembrandt's religious sketches derives from such artistic and cultural influences as Netherlandish realism, Reformation art and theology, and the Catholic Italian and Flemish painting canons. ${ }^{4}$ Rembrandt had a lifelong fascination with a broad range of artistic subjects and styles, and filled many sketchbooks with copies and alterations of the work of his contemporaries and predecessors. ${ }^{5}$ His close observation of the world around him made the emotional realism of his art exemplary, and while Rembrandt's art is never purely descriptive, the Netherlandish tradition of naturalism influenced his attention to commonplace readable gestures. ${ }^{6}$ His artistic practices dovetailed with the spiritual intensity of $17^{\text {th }}$ century Europe that also colours his art. Rembrandt's time was one of deep, personal religious devotion, where Biblical awareness and

4 The artists with whom Rembrandt apprenticed were Italianate "history" painters: Jacob van Swanenburgh of Leiden, Jan Pynas of Amsterdam, and the influential Amsterdam painter of classical and Biblical subjects, Pieter Lastman. Clifford S. Ackley, Rembrandt's Journey, Painter Draftsman, Etcher. (Boston: MFA Publications, 2003), 12; William H. Halewood, Six Subjects of Reformation Art: A Preface to Rembrandt. (Toronto: University of Toronto Press, 1982), 85; For the influence of Flemish artist Peter Paul Rubens on Rembrandt see Gary Schwartz, Rembrandt's Universe. His Art, His Life, His World. (London: Thames and Hudson, 2006), 35, 123, 150.

5 Rembrandt had one of the largest collections of prints in $17^{\text {th }}$-century Netherlands. This included work by Bruegel, Michelangelo, Raphael, Rubens, and Titian, among many others. Bob Haak, Rembrandt, His Life, Work and Times. (London: Thames and Hudson, 1969), 277-278; Halewood, 115.

6 Rembrandt's "storytelling" succeeds because of his accurate depiction of psychological and physical conditions. Ackley, 11, 35; Rembrandt's emphasis on the communicative value of realistic gesture was appreciated in his own day, and characterised his teaching practice. He had students read a Biblical passage and then act it out in order to understand how the subjects would have moved. Arnold Houbraken, De groote schouburgh der nederlantsche konstchilders en schilderessen. (Amsterdam, 1718-1721) Vol. 1, 269 and Vol. 2, 162; Seymour Slive, "Realism and Symbolism in Seventeenth-Century Dutch Painting," Daedalus, 91, (1962), 469-500. 
practice were closely linked with one's family and neighbourhood. Most people prayed often, read religious texts together as a family, attended worship, heard theological debates at public gatherings, and relied heavily on Biblical stories as models of behaviour. ${ }^{7}$ The flavour of this religiously-steeped community informed Rembrandt's artistic study of Old and New Testament subjects.

While the Annunciation sketch is clearly theologically and artistically significant, Art Historians have been unable to articulate its place in the canon of Rembrandt's religious images. ${ }^{8}$ In part, this is because it is a sketch rather than a painting, and because Rembrandt's religious affiliation is uncertain. The Reformation had placed religious minorities at terrible risk, but by the time Rembrandt was born, Dutch society could be characterised as multi-denominational. The Netherlands was officially Calvinist in Rembrandt's time, but in practice diversity flourished. ${ }^{9}$ Rembrandt's mother was Catholic but his father joined the Reformed Church. Rembrandt married into a tightly knit Mennonite family but lived in Amsterdam neighbourhoods distinguished by religious plurality. His Mennonite, Jewish, and Catholic friends worshipped openly there, and he received important commissions from members of the Jewish and various Christian communities. ${ }^{10}$ While it is difficult to identify Rembrandt's religious

7 Paul Zumthor, Daily Life in Rembrandt's Holland. (London: Weidenfeld and Nicolson, 1959), 79.

8 John I Durham, The Biblical Rembrandt. Human Painter in a Landscape of Faith. (Macon, GA: Mercer University Press, 2004); Christopher White, Rembrandt. (London: Thames and Hudson, 1984); Willem Visser't Hooft, Rembrandt and the Gospel. (London: Som Press, 1957), 150.

9 Volker Manuth, "Denomination and Iconography: the Choice of Subject Matter in the Biblical Paintings of the Rembrandt Circle," Simiolus, Vol. 22, No. 4, (1993-94), 235-52; Bernard M.G. Reardon, Religious Thought in the Reformation. (Harlow: Longman, 1995); Leiden, where Rembrandt grew up, was particularly noted for its religious tolerance. Anthony Goodman and Angus MacKay, The Impact of Humanism on Western Europe. (London: Longman, 1990), 151.

10 Rembrandt, Moses with the Tablets of the Law, in Steven Nadler, Rembrandt's Jews. (London and Chicago: Chicago University Press, 2003), plate 1; Franz Landsberger, Rembrandt, the Jews, and the Bible. trans. Felix Gerson. (Philadelphia: the Jewish Publication Society of America, 1946), 9. Rembrandt, The Mennonite Preacher Cornelis Anslo and His Wife in Arthur Wheelock, Rembrandt's Late Religious Portraits. (Washington: National Gallery of Art, 2005), Fig. 10. 
affiliation, we know that he was closely connected through marriage and work to Mennonites, whose theology was founded on pacifism and personal faith. ${ }^{11}$ It is not possible to draw a clear connection between a faith community and Rembrandt's artistic choices about subject and style. What is apparent is that Rembrandt was a keen observer of human nature and of the members of the overlapping communities that he inhabited, and that when his art was theologically inspired, it drew its vibrancy from his religious and social milieus.

In the mid-1630s when Rembrandt sketched the Annunciation, he was engaged in a prestigious commission for the Stadtholder Prince, a series of paintings on the life of Christ. ${ }^{12}$ Although an Annunciation would have been an appropriate addition to the Life of Christ series, Rembrandt's Annunciation sketch is not a preparatory drawing for the series. It would have been atypical of his way of working. Between 750 and 1000 drawings are attributed to Rembrandt, and many of them have no pictorial antecedents. ${ }^{13}$ Much art historical scholarship has been directed toward Rembrandt's paintings, but whereas his

11 Walter Liedtke defines the Mennonite Hendrik Uylenburgh, Saskia's uncle, with whom she and Rembrandt lived for a year, as the most influential person in Amsterdam. W. Liedtke, C. Logan, N. M. Orenstein, and S. S. Dickey, Rembrandt / Not Rembrandt, in the Metropolitan Museum of Art, Vol. II. (New York: Harry N. Abrams Inc., 1995), 155. A $17^{\text {th }}$-century Italian art historian and biographer claimed that Rembrandt was Mennonite, although this is debated in recent scholarship. Filippo Baldinucci, "Life of Rembrandt," from Cominciamento e Progresso dell'arte d'intagliare in rame colle vita de' piu eccellenti maestri della stessa professione. 1686, in ed. Charles Ford, Lives of Rembrandt. (London: Pallas Athene, 2007), 40; Seymour Slive, "Filippo Baldinucci," Rembrandt and His Critics. (The Hague: M. Nijhoff, 1988 and 1953), 104-115. According to Stephanie Dickey, in Rembrandt's treatment of Mennonite martyrdom, he was "thinking like" a Mennonite. "Mennonite Martyrdom in Amsterdam and the Art of Rembrandt and His Contemporaries," Proceedings of the American Association of Netherlandic Studies, Vol. 9, (1996), 98;

12 Christian Tumpel and Astrid Tumpel. "Rembrandt's Commission from Prince Frederick Hendrick," Rembrandt: Images and Metaphors. trans. A. Bader and I. Bader. London: Haus Publishing, 2006, 92-103. The sketch also corresponds to Rembrandt's growing interest in the female subject. In 1635 Rembrandt was newly married, and there is a marked increase in the number of his drawings of women, in which he explores themes of domesticity, passion, introspection, and familial relationships.

13 Schwartz, 13; Egbert Haverkamp-Begemann, "Rembrandt," Encyclopedia of World Art. (London and Toronto: McGraw-Hill Book Co.) Vol. XI, 917. 
paintings were often shaped by conditions of patronage, his sketches, on the other hand, were often meant entirely for himself, and therefore provide us with a glimpse into the artist's inner world. ${ }^{14}$ Indeed, his sketches can be considered analogous to a personal diary, providing insight into his entire oeuvre. Rembrandt's sketches are more honest and direct than his paintings, less cluttered in their conception, and more naked in their emotion.

Rembrandt's focus on non-preparatory drawing was legendary, as was his ability to represent human feeling in poignantly succinct forms. Rembrandt's sketches of the 1630s-1650s reveal an intense study of artistic method and human psychology, functioning like pictorial shorthand. They do not so much narrate Biblical stories, as refer to them, with the focus on human emotion and experience. Rembrandt repeatedly returned to subjects from the Old and New Testaments, seemingly exploring thematic and stylistic variation, and studying how to communicate the spiritual subtleties of the human condition. His sketches reveal subjects' spiritual experiences through visual oppositions of light/dark, high/low, and gentleness/strength, for example. ${ }^{15}$ Subtle variation in subjects' physical movement evokes the emotional tenor of an event, while lines and tones suggest rather than describe form. Rembrandt's Annunciation is very much in keeping with his practice of exploring the human elements associated with key religious themes. Like other sketches, it shows the artist's ability to portray tension and to visually mirror the emotional states that reverberate among characters in his narratives.

Rembrandt's facility with sketching made it ideal for expressing the acute inner struggles of Biblical subjects. The practice of personalizing one's understanding of the Bible was akin to Rembrandt's intense

14 Seymour Slive, "Religious Subjects," Rembrandt Drawings. (Los Angeles: The J. Paul Getty Museum, 2009), 195-219; Holm Bevers, Peter Schatborn, and Barbara Welzel, Rembrandt: the Master and his Workshop, (Vol. II, Drawings and Etchings). (London and New Haven: Yale University Press, 1991); Seymour Slive, Drawings of Rembrandt. (New York: Dover, 1965); Marijn Schapelhouman, Rembrandt and the Art of Drawing. (Amsterdam: Rijksmuseum, and Zwolle: Waanders Publishers, 2006), 18, 61.

15 This may relate to the rhetorical tradition of juxtaposing opposites. David R. Smith, "Towards a Protestant Aesthetics: Rembrandt's 1655 Sacrifice of Isaac," Art History, Vol. 8, No. 3, (Sept. 1985), 290-302; Joseph Koerner, "Rembrandt and the Epiphany of the Face," Source: Notes in the History of Art, Vol. 12, (1986), 5-32. 
sketched responses to the Bible. Sketching in pen, ink, and wash required being close to the paper; a process more like reading than is the more removed, meticulous easel painting. Like the practice of closely reading and contemplating religious texts, sketching encouraged a personal, emotionally charged focus on intuitively meaningful details. The immediacy of the sketching process allowed Rembrandt to subtly layer transitional moments with sacred and secular meanings, and to conflate not only narrative time, but also symbols, identities, and meanings. In sketches that emphasize closeness and touch, Rembrandt's subjects evoke the heightened emotional intensity surrounding trauma, transition, and God's active grace.

One theme that runs through many of Rembrandt's sketches is the depiction of a physical embrace between a human and a divine figure. The popularity of this motif in Rembrandt's drawings can be linked to the passion of medieval mystics' religious experience that continued to set a tone of spiritual fervour in Rembrandt's Netherlands. ${ }^{16}$ Reformation concepts of grace and the Word had strong ties with mystical theology: the $17^{\text {th }}$-century emphasis on one's personally experiencing a benevolent God is rooted in the medieval mystical notion of a reunion of estranged humanity with loving divinity, a theme that reappears in Rembrandt's sketches. At the centre of the lively religious debate that characterized Rembrandt's society was the question of how God's grace functioned. More than a hundred years before Rembrandt painted, Luther had redefined the concept of "God's justice" to emphasize that people did not have to be perfect, cooperative, or even interested in their own salvation, because grace operated solely as God's will. ${ }^{17}$ For Luther and Calvin people could not

16 "There may be a sense in which the piety of Europe on the eve of the Reformation was, in Reinhard Bendix's general description of historical process, the 'style of life of a distinct status group' (women) that eventually became the 'dominant orientation' of Christianity." Caroline Walker Bynum, Fragmentation and Redemption. Essays on Gender and the Human Body in Medieval Religion. New York: Zone Books, 1992, 78; and see footnotes below. 17 Medieval church dogma had required three elements for salvation: God's healing grace; cooperation with grace by complying with church authority; and priestly absolution of sins. Steven Ozment, The Age of Reform, 12501550, An Intellectual and Religious History of Late Medieval and Reformation Europe. (New Haven: Yale University Press, 1980), 210; Stephen Pfurtner argues that the Luther versus Catholic debate about grace was caused by 
initiate or affect reconciliation with God. ${ }^{18}$ Humankind was tragically inadequate, trapped in an existence of pain and ignorance that could only be relieved through God's grace, which would be freely and unilaterally given. In Calvin's words, nothing other than God's grace could close the "distance between the spiritual glory of the Speech of God and the abominable filth of our flesh." ${ }^{19}$ For Early Modern Anabaptists, grace existed in humans, salvation required human cooperation, and humans possessed free choice, but salvation still depended upon God and was sola gratia Dei. ${ }^{20}$ The widespread debate about God's mysterious role in human salvation informs Rembrandt's sketches of religious transformation.

The early Reformation theology that came to influence Rembrandt's $17^{\text {th }}$-century Netherlands favoured a direct personal connection with God. This had clear precursors in medieval themes of love and closeness, and in the inner-worldly emotionalism of the medieval religious experience. ${ }^{21}$ The Early Modern emphasis on bridging the human/divine gap is indebted to the highly emotional mysticism that influenced Luther: the search for meaningful spirituality sought to

a change in consciousness but even more importantly by the resulting linguistic change, particularly regarding "certainty of grace." Catholics thought it presumptuous to assume that God would save one in the absence of appropriate behaviour, serious intention, and an appreciation for God's mysterious power. Lutherans argued that the Catholic rejection of the certainty of grace pointed to an abrogation of faith in God's Word. Luther and Aquinas on Salvation. (New York: Sheed and Ward, 1964), 123.

18 According to Luther, "We work nothing, we render nothing unto God, but only we receive and suffer another to work in us, that is to say, God." Luther in Halewood, 7.

19 Calvin in Halewood, 10; Léon Wencelius, "Réalité Rembrantienne et Grace Générale Calvinienne, " Calvin et Rembrandt. (Paris: Société d'édition "Les Belles Lettres", 1937), 65-73.

20 Packull, 178.

21 For example, early Anabaptist theology retained the mystical motif of the immanence of God. "In the original dissent of the South German Anabaptists from institutionalized Catholicism and confessionalized Protestantism we find the echoes of the mystical appeal to the immanence of God." (...) "Early South German Anabaptism inherited much of its theological inspiration from an earlier medieval, more specifically popularized mystical tradition." Packull, 34, 176; R. Emmet McLaughlin, "Luther, Spiritualism and the Spirit," in eds. Steven Ozment, Marc R. Forster, Benjamin J. Kaplan, Piety and Family in Early Modern Europe. (Aldershot, UK: Ashgate Publishing Ltd., 2005), 28-49. 
replace what reformers saw as corrupt church authority with a personal relationship with God, fostered through individual experience of Him and His Word. The doctrine of justification by grace can be traced through Luther, Calvin, the radical reformers, and Erasmus, to mysticism, St. Augustine, and St. Paul. ${ }^{22}$ By the $15^{\text {th }}$ Century, the religious experience of much of the laity was mystical, intuitive, and emotionally fervent, a form of piety that had survived from the $12^{\text {th }}-$ and $13^{\text {th }}$-century nuns, beguines, and laity of the Low Countries. ${ }^{23}$ As a monk Luther had taken mystical writers seriously and created from the monastic "living faith" his belief in a Living God who people would know through his Word. Luther's affinity for the writing of St. Augustine ensured that medieval mysticism would remain a major influence of the Reformation. ${ }^{24}$ Luther sympathized with Augustine's treatment of theology as a path of love. Augustine identified love with pondus, or gravity, and claimed that people orbit around either self-love or love of God. Fundamental to this theory was the notion of the void between the two types of love; only God could make the leap between the old orbit and the new, through His grace alone. A central concept of the theology of German mystic Eckhardt that greatly impressed Luther was the unio mystica that would unite the divine with the human soul. ${ }^{25}$ Also, in 1516 and 1518, bracketing his

22 "Although the theologies of the reformers are many-sided and operate on different levels, they do reveal their shared tendencies (...) The most important of these shared tenets could be said to be: the justification by God's grace (sola gratia) through man's faith (sola fide) as revealed in the Gospel as the Word of God (sola scriptura)." Peter Blickle, "Social Protest and Reformation Theology," in Peter Blickle, H. Rublack, and W. Schulze, Religion, Politics and Social Protest. (London: George Allan and Unwin Publishers Ltd., 1984), 12. "St. Augustine, considering that man's trust in his own powers was a danger to true piety, (was) inclined, just as St. Paul, to favour grace. (...) Free will and grace work together, but grace is the leader of the venture and not merely associated with it." Erasmus, De libero arbitrio, 44, in Peter I. Kaufman, Augustinian Piety and Catholic Reform. (Macon, GA: Mercer University Press, 1982), 136.

23 Bynum, 77.

24 Heiko A. Oberman, "The Meaning of Mysticism from Meister Eckhart to Martin Luther," The Reformation: Roots and Ramifications. (Grand Rapids, MI: William B. Eerdmans Publishing, 1994), 88.

25 Oberman, "The Meaning of Mysticism," 85; "Salvation was a bringing back together of all diversity into unity through the unio mystica." Packull, 21, 23; McLaughlin, 29, 31, 49. 
distribution of the Wittenberg Theses, Luther republished German Theology, the writing of an anonymous $14^{\text {th }}$-century mystic who promoted a quietist personal experience of and individual union with God. Anabaptists and other radical Reformers widely paraphrased and republished this work, rendering the doctrine ubiquitous. ${ }^{26}$ The mystical tradition that drew on the writings of the Apostle Paul and was communicated through Luther and radical Reformers into the Early Modern Amsterdam of Rembrandt highlighted the incarnation of a living God whose grace melded fallen humanity into its Godhead. The passionate introversion of religious women's mystical marriage to God was integrated into the "dominant orientation" of Reformation theology, and through it, reverberated into the $17^{\text {th }}$-century. ${ }^{27}$ In Rembrandt's time, theologians were concerned with the question of how the divine and the human realms intersected, an issue that points to the type of mystical human/divine connection that Rembrandt treats in his Annunciation sketch.

The $17^{\text {th }}$-century artistic trend, among Protestant and Catholic artists, of portraying Christ's humanity, echoes the medieval mystical concept of the humanation of God at the Incarnation. Rembrandt's Annunciation sketch alludes to the paradoxical union of the most exalted with the most humble that occurs through the Incarnation, where the crossing of the gap between these levels is symbolized as a divine embrace. The mystic Angela of Foligno first used the term humanation as "the soul in this present life knows (...) the lesser in the greater and the greater in the lesser, for it discovers ... humanated God, that is, divinity and humanity united and conjoined in one person." ${ }^{28}$ God's becoming human required the fundamental resolution of opposites through the uniting of the spiritual with the material. Drawing on contemporary understandings of physiology

26 Muntzer, Karlstadt, Haetzer, Denck, Franck, Castellio, and Wiegel relied on it. Steven E. Ozment, Mysticism and Dissent: Religious Ideology and Social Protest in the Sixteenth Century. (New Haven: Yale University Press, 1973), 15-16; Packull, 24.

27 Bynum, 78.

28 Angela of Foligno in Bynum, 90; "The general medieval ethos was strongly impressed with the immediacy of the supernatural, and the widespread religious mood sought fulfilment in direct contact and union with God. Mystical union thus, ontologically perceived, implied the deifying transformation of man." Packull, 21-22. 
and natural philosophy, theological writing from the $12^{\text {th }}$ through the $14^{\text {th }}$ Centuries investigated the integration of body and soul. ${ }^{29}$ The notion of the duality of intellect/body, reason/emotion, and male/female was less a fully-fledged impenetrable dichotomy than a concern with bridging the distance between the material and the spiritual. Medieval mystical writers who equated "female" with "material" naturally thought of human contact with the divine in nuptial terms. In commentaries that survive from the $4^{\text {th }}$ Century, Christ's Incarnation was equated with the marriage of the human soul to God. ${ }^{30}$ In this way, the Incarnation foreshadowed the union of Christ and church, and the promised marriage of every human soul with Christ. In Augustine's words,

"Like a bridegroom, Christ came forth from his chamber, and with a presage of His nuptials He reached the marriage couch... and mounting it, consummated His marriage... and thereby forever joined the woman to Himself." 31

This metaphor of spousal union was paramount to the mystical tradition, and it influenced art, poetry, prayer, and religious practices. Mystics' descriptions of their spiritual experiences blur the distinction between the spiritual and the physical, and point to a highly personal encounter with God. In the $12^{\text {th }}$ Century Hildegard of Bingen wrote of the human/divine marriage, and had her nuns dress in bridal gowns to receive Communion. ${ }^{32}$ Associated with this conjugal bliss was women's bodily experiencing of God's presence. Women wrote of tasting God, kissing Him, and entering His heart. Mechtild of Magdeburg reported to members of her order, "Then the Lord God spoke to me: 'Grant that I may cool the glow of My Godhead, the

29 Medieval writers associated the body with the feminine through Aristotelian conception theory: the mother provided the matter of the fetus and the father the spirit. Because Christ had no human father, his matter came only from Mary, making her the reliquary of the divine spirit. Bynum, $100,148-149$.

30 Jerome (c. 347-419) in Carla Gottlieb, The Window in Art. (New York: Abaris Books, 1981), 84.

31 Augustine (354-430) in Robert Baldwin, "Marriage as a Sacramental Reflection of Christ's Passion: The Mirror in Jan van Eyck's Arnolfini Wedding," Oud Holland, 98.2, (1984), 59.

32 Bynum, 134. 
desire of My humanity and the delight of My Holy spirit in thee." In another vision she cried, "Ah! Love! Fling me down under Thee, Gladly would I be vanquished." ${ }^{33}$ Indeed, physicality itself was redeemed and valued by the humanated God, making the Incarnation central to the redemption of the whole person. ${ }^{34}$ When Reformers, asserting dogma about faith and grace, promoted building personal relationships with God, they echoed the medieval mystical notion of a God who would cross the distance between the human and divine realms.

The meeting of the physical and spiritual worlds over the distance that separated them was reflected in theological writing and in art as a wall that, paradoxically while it divided, simultaneously bound together those on either side. This wall motif was part of a tradition going back to the Old Testament Song of Solomon, verse 2:9, "Behold, He standeth behind our wall, He looketh forth at the windows, shewing Himself through the lattice." 35 The material world was the wall that separated humankind from God, yet the senses were the window through which one could see God and He could touch us. The symbolism of the wall that could be pierced by the grace of God survived into the medieval era, for example in the $13^{\text {th }}$-century Sermon on the Canticles by the Cistercian Abbot John of Ford:

\begin{abstract}
"To behold the majesty of God, the wisdom of God, the goodness of God, they had not need of relying on many steps or immersing themselves in the complications of disputed points. They had simply to return the gaze of their beloved, standing behind our wall, and gazing on us through the window of our senses. Only the thickness of one wall, only one step, separated them from the ineffable contemplation of the eternal light which is in heaven." ${ }^{36}$
\end{abstract}

33 Mechtild of Magdeburg in Scheper, 983.

34 Julian of Norwich wrote of humanity's sensuality not just loved and saved, but actually given being by a "human God" through the Incarnation. Bynum, 149.

35 Robert Baldwin, "A Window from the Song of Songs in Conjugal Portraits by Fra Filippo Lippi and Bartholomaus Zeitblom," Source: Notes in the History of Art, Vol. 5(2), (1986), 7.

36 Bible Moralisée, Illustration to Song of Songs 2:9, in Robert Baldwin, "Gates Pure and Shining and Serene," in eds. Konrad Eisenbichler and Philip Sohm, The Language of Gesture in the Renaissance, (Renaissance and Reformation), Vol. X, No.1, (1986), 31. 
God's ability to bridge the human/divine gap was given form in early images of Christ reaching through a wall to his earthly bride. In a $12^{\text {th }}$-century frontispiece Christ the spouse, labelled Sponsus, embraces his Sponsa, symbolizing Mary and the Church, but reaches through the wall of the physical world to his other bride, the human soul, labelled "Saved Humanity" ${ }^{37}$ The symbolism of Christ's Incarnation as the marriage of the divine and the human remained prevalent in Northern European art and theology from the 1400s through the 1600s. A $15^{\text {th }}$-century Dutch woodblock illustrating this theme in the Canticum Canticorum appears beside the text, "The Bridegroom requests, 'Open to me, my sister, for my head is full of dew.' And the Bride responds, 'I opened the bolt of my door to my beloved. I have put off my garments." ${ }^{38}$ In the $15^{\text {th }}$ and $16^{\text {th }}$ Centuries, concepts of the mystical marriage and the wall that it crossed influenced both Annunciation paintings and formal portraits of betrothed couples, who commissioned paintings of themselves mutually gazing across architectural barriers. ${ }^{39}$ Rembrandt responded to these theological and artistic traditions when he sketched the divine touch that overcame obstacles to instigate momentous transformations.

Rembrandt's Annunciation and other sketches demonstrate his unique use of the motif of the embrace, and the efficacy of his distance/closeness metaphor as a visual cue to concomitant inner conditions. ${ }^{40}$ The symbolic value of physical closeness in Rembrandt's sketches has the effect of focussing attention on subjects' inner emotional states. Subjects' touching and embracing coincide with spiritual or psychological causation or connection such as the spiritual transformation commensurate with touch in his Christ Baptized in the Jordan and Satan Showing Christ the Kingdom. ${ }^{41}$ In

37 Honorius Manuscript, frontispiece. Sponsus and Sponsa, in Baldwin, "Gates Pure," 34.

38 Dutch School, Canticum Canticorum, 1460-70, in Gottlieb, 277. Compare with Petrus Christus, Annunciation c. 1445, Met, N.Y.

39 In wedding portraits this trope symbolized the spiritual meeting of everfaithful souls, and the containment of passion within divinely sanctioned marriage. Baldwin, "A Window," 12; Fra Filippo Lippi, Portrait of a Man and a Woman at a Casement, 1445, and Bartholomaus Zeitblom, Marriage Portrait, 1505, in Baldwin, "Gates Pure," 29.

40 Classical artists may have avoided painting embraces because they are difficult to depict two-dimensionally. Smith, 297.

41 Rembrandt, Christ Baptized in the Jordan, in Owen S. Rachleff, 
Rembrandt's Abraham Dismissing Hagar sketch, Abraham uses one hand to counsel his beloved Hagar while the other hand expresses his reluctance to break his tie with his son Ishmael. ${ }^{42}$ Emotion is portrayed as communal in Tobias Healing His Father's Blindness, where the main characters cluster closely around the blind father, drawing the viewer in to the emotional tension centring around the transformative moment of the son's hands on his father's eyes. ${ }^{43}$ Whereas Rembrandt's painted Lucretia portrays her alone and confident, his sketch of her focuses intensely on the futile anguish of her final moments, cradled in the arms of her husband and her father. ${ }^{44}$ Again, physical and emotional connection pervades Rembrandt's Lamentation sketch, where Christ and Mary's faces share a single line: Mary's nose delimits Christ's profile; Christ's nose outlines Mary's chin; and they seem to have one communal body. ${ }^{45}$

Rembrandt's Biblical sketches illustrate divine intercession in human affairs by fusing human psychology with divine/human proximity. Angels represent God in Rembrandt's sketches, and they touch humans as a metaphor for God's healing, teaching, guiding, and salvational power. They fly, they walk, and they talk. ${ }^{46}$ But to mark God's active intercession in human life, Rembrandt's angels make physical contact. ${ }^{47}$ This angelic touch often accompanies God's transmission of information that will radically alter people's lives.

Rembrandt's Life of Christ. (New York: Abradale Press, 1966), 36; and Rembrandt, Satan Showing Christ the Kingdom, in Rachleff, 39.

42 Rembrandt, Abraham Dismissing Hagar, in Benesch, Fig. 656.

43 Rembrandt, Tobias Healing His Father's Blindness, in Julius S. Held, Rembrandt and the Book of Tobit. Northampton, Mass: Gehenna Press, 1964, Fig.26.

44 Rembrandt, Lucretia, paintings, in A. Bredius, The Paintings of Rembrandt. (Vienna: Phaidon, 1937), Figs. 484, 485; Rembrandt, Lucretia, drawing in Benesch, Fig. 136.

45 Rembrandt, Lamentation, in Benesch, Fig. 117.

46 See these very engaging examples. Rembrandt, Manoah's Offering, in Benesch, Fig. 210; Rembrandt, The Angel Departs from Manoah and His Wife, in Benesch, Fig. 209; Rembrandt, Tobias and 'Azarius' Walking, in Held, Fig. 10; Rembrandt, Abraham and the Angel, in Benesch, Fig. 158.

47 Rembrandt, The Angel Appearing to Hagar, and Ishmael in the Wilderness, in Bevers, Fig. 32; Rembrandt, The Angel Appearing to Elijah in the Desert, in Benesch, Fig. 1182; Rembrandt, The Angel and Saint Peter, in Benesch, Fig. 735; Rembrandt, The Angel Appears to Manoah, in Benesch, Fig. 94. 
The Early Modern understanding of humankind's close personal relationship with God and His healing grace illuminates Rembrandt's imagery of the divine embrace. A recurring theme in Rembrandt's religious sketches is the relief of human anguish through divine mercy. In such sketches intense spiritual transformations appear as moments of confusion and despair, in which God, as angel, actually grabs people and holds them close. The firmness on the part of the angels echoes the $17^{\text {th }}$-century belief in God's salvific will and power. The motif of the embrace is paramount in Rembrandt's exploration of the paradox of the all-powerful God rescuing the powerless human. Sketches of Christ on the Mt. of Olives present Christ's desperate emotional and spiritual struggle and the magnitude of divine salvation, represented by an angelic embrace. ${ }^{48}$ In the Agony in the Garden sketch, an angel kneels on the earth, staring into Christ's face with his arms around Christ's shoulders, poised to cajole or wrestle him out of his suffering. ${ }^{49}$ In Rembrandt's etching of Abraham's Sacrifice, the strength of Abraham's grip on the knife has its counterpoint in the firmness of the angel whose arms surround Abraham, rendering visible the strength of God's salvation..$^{50}$

Rembrandt's sketches conflate layers of meaning, superimposing the passage of time upon the effects of time. In doing this they reveal their debt to the Reformation theology that understood God's grace to be concurrent with the message of this grace. For Reformers, grace was inherent in God's nature, and the existence of God's grace in His Word created a simultaneous healing effect on the faithful. This simultaneity is represented in some of Rembrandt's most powerful sketches. One of the Magi Kneeling Before the Virgin and Child

48 Rembrandt, Christ on the Mt. of Olives, in Benesch, Figs. 122, 151, 180. 49 Rembrandt, Agony in the Garden, in Kenneth Clark, An Introduction to Rembrandt. (London: John Murray, 1978), 140. One painting that suggests this theme is Jacob Wrestling with an Angel. It relates the Biblical story in which, after a long night of intense physical struggle, Jacob is blessed, and walks away, now lame, saying, "I have seen God face to face." Estelle M. Hurll, Rembrandt. (Cambridge: Riverside Press, 1899), 5; Rembrandt, Jacob Wrestling with an Angel, painting, in Halewood, Fig. 61.

50 Rembrandt, Abraham's Sacrifice of Isacc, etching, in Halewood, Fig. 62; Rembrandt, Abraham's Sacrifice, in Benesch, Fig. 105; Shelley Karen Perlove, Impressions of Faith, Rembrandt's Biblical Etchings. (Dearborn: University of Michigan-Dearborn, 1989), 17, 66. 
depicts Jesus's birth as concurrent with his service to humanity. ${ }^{51}$ Here the elderly kneeling magus who symbolizes humanity is separated from the divine by a dark swath across the floor. But Jesus is being passed across this dividing line immediately upon his birth, evidence of which still appears as blood in Mary's lap. Simultaneity, like transformation, is also at the heart of Rembrandt's Healing of the Paralyzed Man, in which the invalid is already beginning to move his leg while he is being blessed and healed..$^{52}$ The complex story of Adam and Eve involves the concurrence of temptation with guilt, togetherness with separation, paradise with rejection, and of the fall from natural grace with the need for Christ's birth. In Rembrandt's sketch of this subject, temptation casts its dark shadow of punishment off Eve's body onto Adam's face even as Adam barely begins to reach toward the forbidden fruit. ${ }^{53}$ Rembrandt's juxtaposing of such discordant visual and emotional elements suited the Early Modern interest in the paradoxical nature of Christianity, fundamental to which was the mystery of the Incarnation of God in Christ.

Major $17^{\text {th }}$-century religious and artistic concerns converge in Rembrandt's Annunciation sketch: this extraordinary image conflates the Annunciation with the Incarnation; Reformation grace with the mystical marriage; and the divine promise of salvation with the human emotions engendered by that pledge. The Annunciation marked the close intertwining of God and humankind that provides the core of Christian doctrines of salvation. The Incarnation bridged the gap between God and humanity by bringing forth a being who embodied both. The Incarnation/Annunciation moment that took place between Mary and the divine ushered in the relationships between Mary and Christ, the Church and Christ, and God and saved humanity. Steeped in the tradition of mystical passion, the Reformation emphasis on a direct personal relationship with God dovetailed in Rembrandt's Annunciation sketch with his emotionally vibrant sketching style. In his Annunciation, visual antitheses highlight the simultaneous transformation of Mary and of all the Christian faithful, while impassioned gestures personalize the marriage of the spiritual with

51 Rembrandt, One of the Magi Kneeling Before the Virgin and Child, in Benesch, Fig. 135; Mieke Bal, Reading Rembrandt: Beyond the Word-Image Opposition. (Cambridge: Cambridge University Press, 1991), 207, 212. 52 Rembrandt, Healing of the Paralyzed Man, in Benesch, Fig. 130.

53 Rembrandt, Adam and Eve, in Benesch, Fig. 194. 
the human that occurred through the Incarnation.

The passionate embrace, the divine/human contact, and the psychologically poignant expressions and gestures make Rembrandt's Annunciation so moving. Early Modern portrayals of the Annunciation typically included such readable cues as the Bible, the dove, the cat, and Mary's lilies of purity, markers that Rembrandt has included. ${ }^{54}$ However, like their predecessors in the mystical marriage, such contemporary images of the Annunciation also emphasized the void that separated the divine and human realms. In $15^{\text {th }}$ - and $16^{\text {th }}$-century art, the spiritual and psychological distance at the Annunciation was often symbolized either by a doorway or by visually divisive pillars. ${ }^{55}$ These signs of distance separating Mary from her messenger can be contrasted with the inventive motif of closeness and contact in Rembrandt's $17^{\text {th }}$-century sketch. Where earlier images of the Annunciation had kept the divine and the human visually separated, Rembrandt's sketch illustrates the imminence of salvation by accentuating humanity's proximity to the divine: a direct personal relationship with God is symbolized in a passionate embrace evocative of the divine/human resolution that characterized the mystical marriage.

In Rembrandt's Annunciation, a zealous angel leaps across the void and holds humanity in His arms, reconciling the divine/human gap and demonstrating the transformative power of God's grace and his active connection with humankind. The meaning and effect of God's grace are simultaneously realized while the message of salvation is being communicated, and God is being rendered human. The male angel swoops down, framing the scene with his massive wings, leans over Mary, and grasps her by the arm. He stares pointedly into her face, his hand seeming to simultaneously clasp her forearm, hold her

54 Don Denny, The Annunciation from the Right from Early Christian Times to the Sixteenth Century. (New York and London: Garland Publishing, Inc., 1977), 128; Leaf from a Sienese Gradual, Annunciation in Letter V, c. 1470; and Lorenzo Lotto, The Annunciation, c. 1527, Museum of Villa Colloredo Mels, Recanti, in Gottlieb, 127, 324.

55 Fra Angelico, Cortona Annunciation, c. 1433, Museo del Prado, Madrid; and Fra Filippo Lippi, Annunciation, c. 1435/1440, National Gallery of Art, Washington, DC.; Petrus Christus, attrib. (Flemish School), Annunciation, Met, New York. 


\section{Catherine M. Nutting}

shoulder, and cup her hair. Mary drops her book and turns toward the viewer with a look that combines layers of human emotion: innocence; passion; and foreboding, the dark lines on Mary's lap foreshadowing her future roles as the throne of Christ and the altar of the Eucharist. The tension of this complex layering of causes and repercussions is heightened through the visual antithesis of the powerful male angel leaning vertically over the seated earthly female. Tellingly, her lily of purity and virginity has already dropped onto the floor: the divine/ human gap has been bridged concurrently with the transmission of God's message. God in his grace and power has crossed the distance to begin the process of humanation, through the human/divine embrace. 
Devotional Zeal and Mystical "Humanation" in Rembrandt's Annunciation Sketch

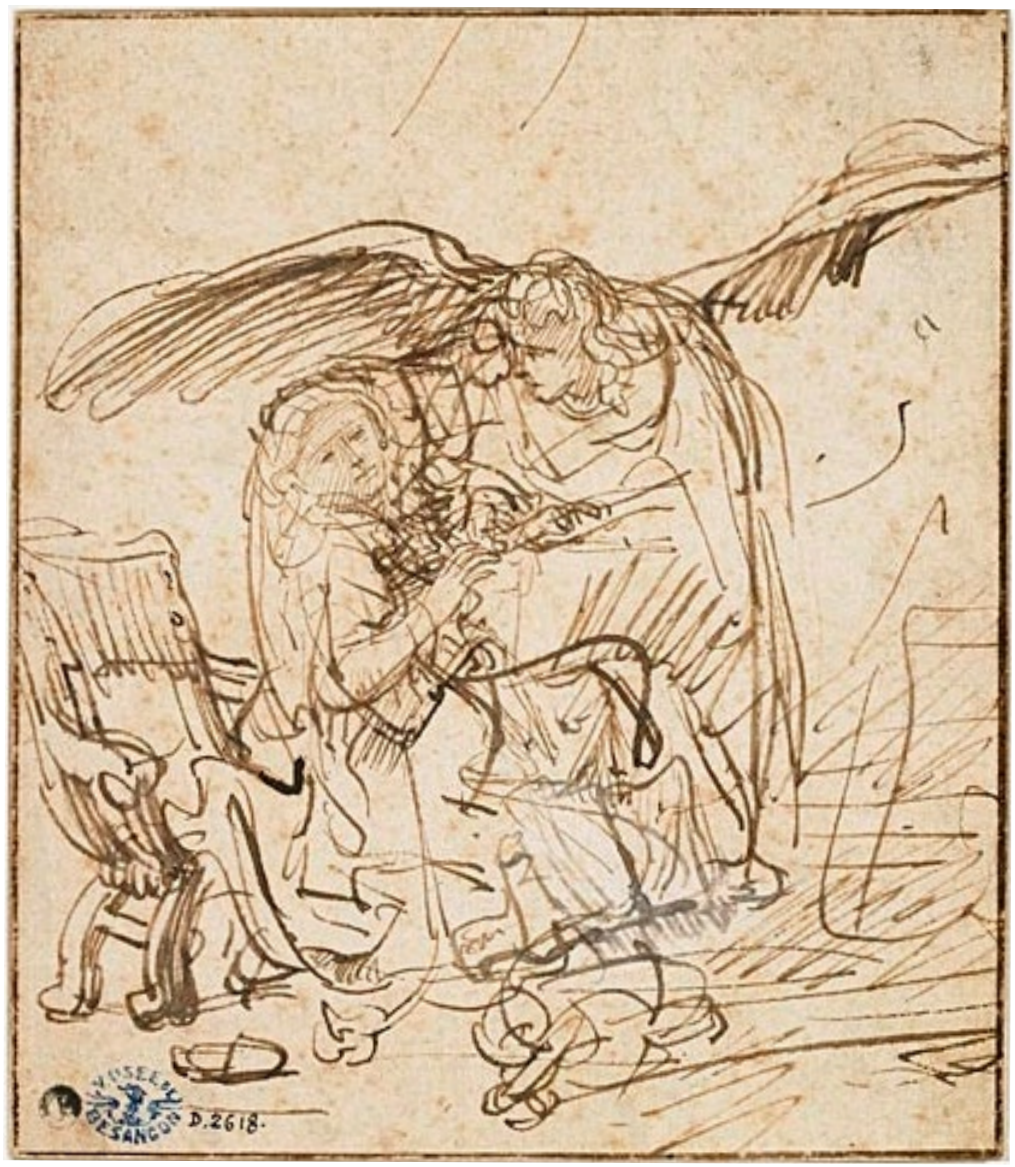

Fig. 1. Rembrandt, Annunciation, 1635, Besançon Museum of Fine Arts and Archaeology, inv. D. 2618. 


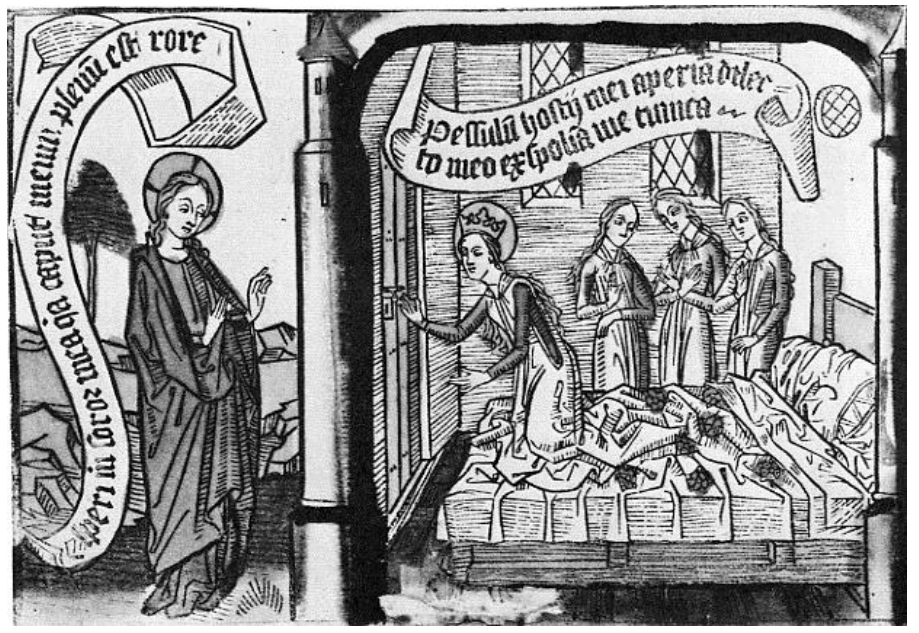

Fig. 6. Dutch School, Canticum Canticorum, (c.1460-70) Bayerische Staatsbibliothek, Munich.

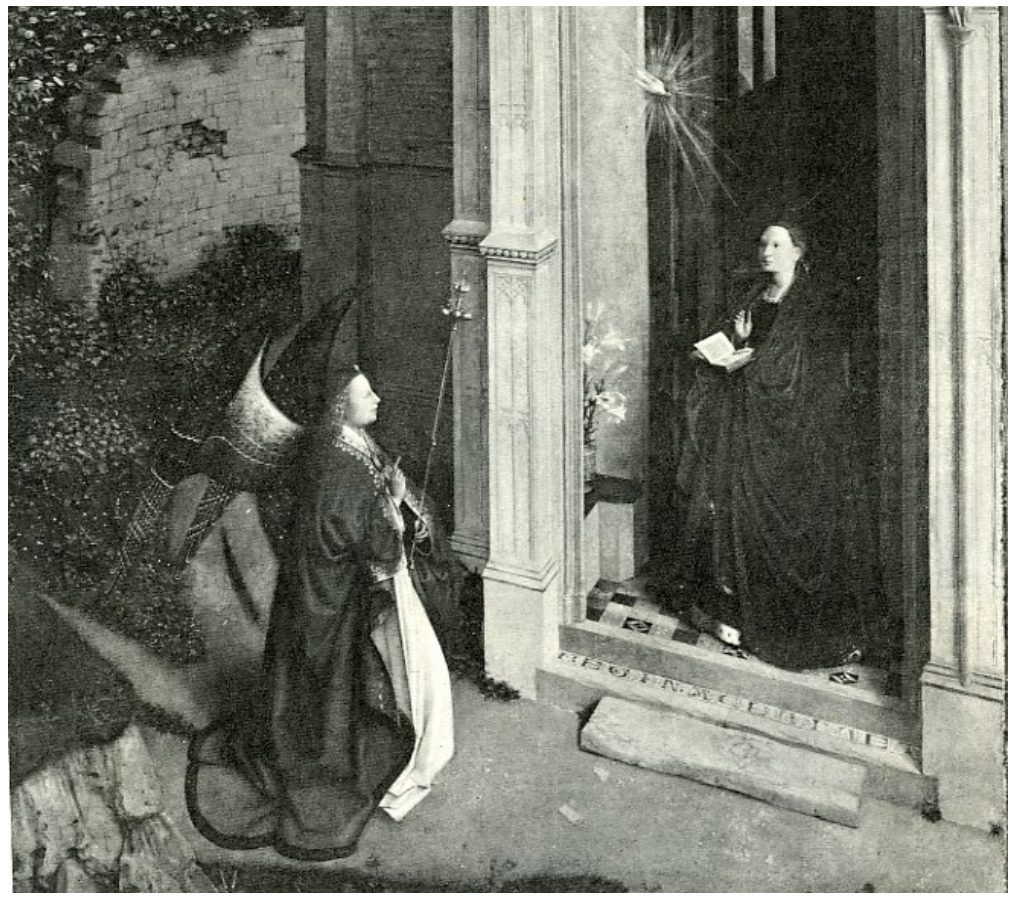

Fig. 7. Petrus Christus, attrib. (Flemish School) The Friedsam Annunciation, detail, (c.1440-50), Met, N.Y. 
Devotional Zeal and Mystical "Humanation" in Rembrandt's Annunciation Sketch

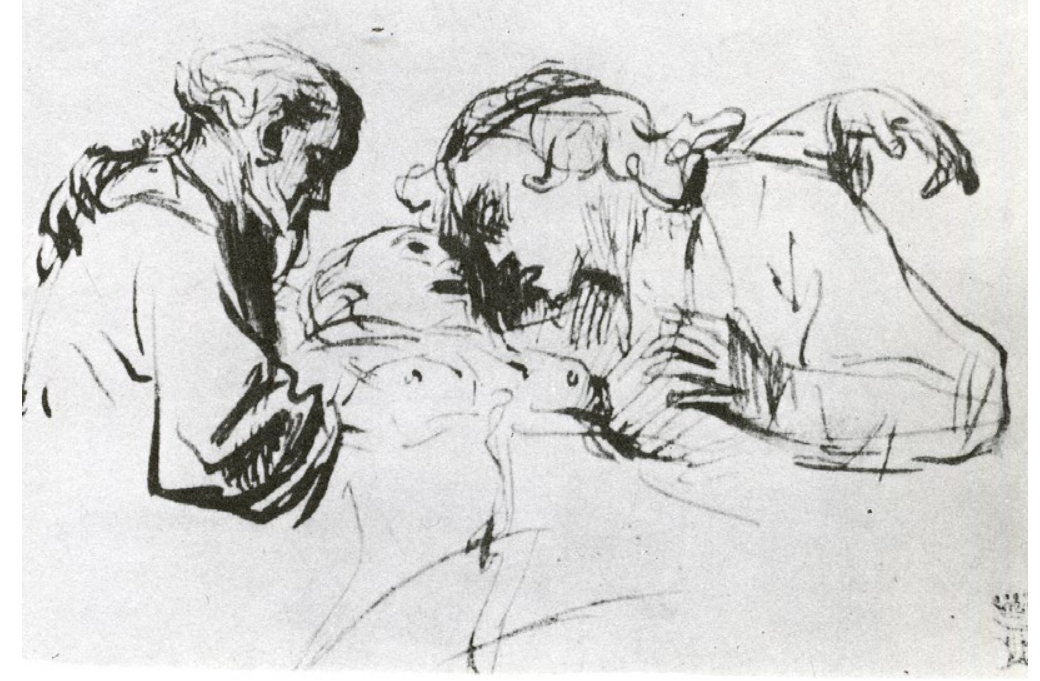

Fig. 15. Rembrandt, Lucretia, sketch.

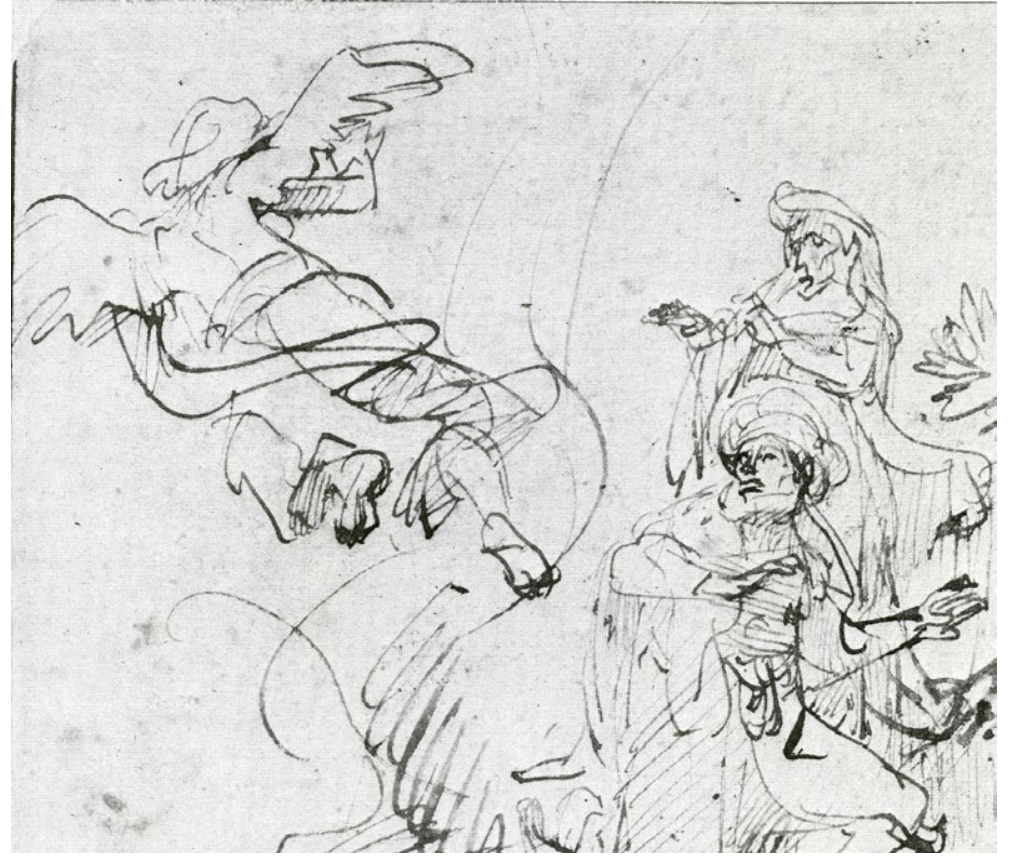

Fig. 17. Rembrandt, Manoah's Offering. 


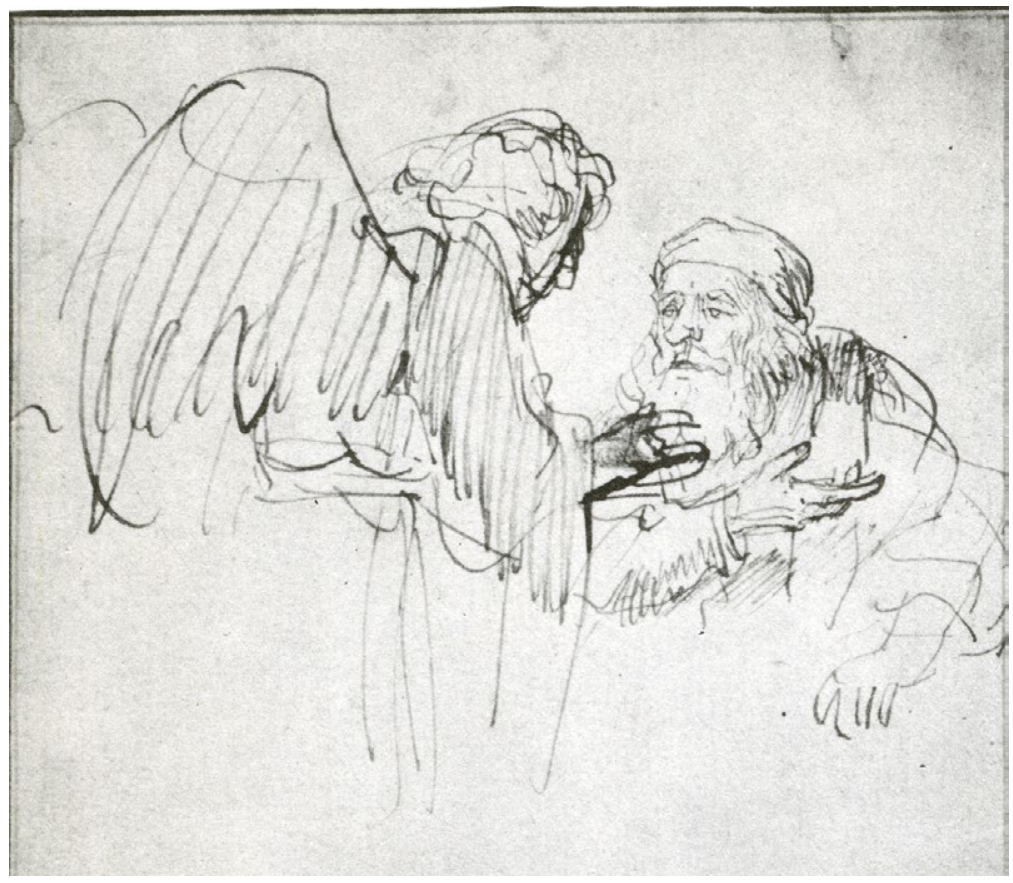

Fig. 20. Rembrandt, Abraham and the Angel.

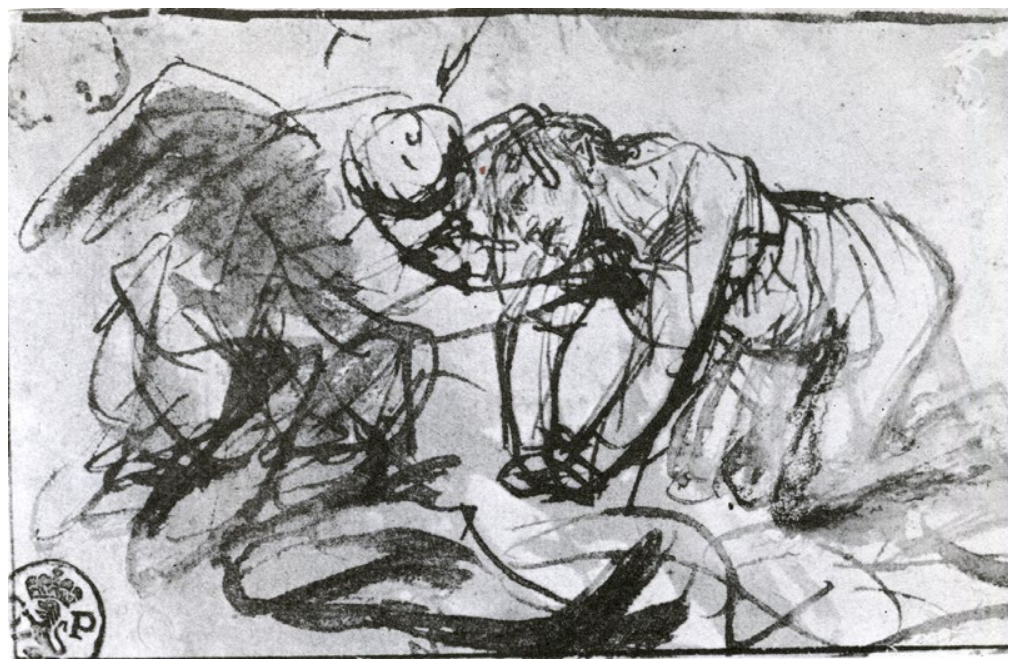

Fig. 26. Rembrandt, Agony in the Garden. 
Devotional Zeal and Mystical "Humanation" in

Rembrandt's Annunciation Sketch

\section{List of images}

Fig. 1. Rembrandt. Annunciation, 1635, 14.4 x $12.4 \mathrm{~cm}$, brown ink and white gouache, Besançon Museum of Fine Arts and Archaeology, inv. D.2618; and Benesch, Fig. 116.

Fig. 2. Rembrandt, Moses with the Tablets of the Law, in Nadler, Plate 1.

Fig. 3. Rembrandt, The Mennonite Preacher Cornelis Anslo and His Wife, in Wheelock, Fig. 10.

Fig. 4. Bible Moralisée, Illustration to Song of Songs 2:9, in Baldwin, "Gates Pure," 31.

Fig. 5. Honorius Manuscript, Sponsus and Sponsa, $12^{\text {th }}-$ C., in Baldwin, "Gates Pure," 34.

Fig. 6. Dutch School, Canticum Canticorum, 1460-70, in Gottlieb, 277.

Fig. 7. Petrus Christus, attrib. (Flemish School) Annunciation, Met, N.Y.

Fig. 8. Fra Filippo Lippi, Portrait of a Man and a Woman at a Casement, 1445, in Baldwin, 28.

Fig. 9. Bartholomaus Zeitblom, Marriage Portrait, 1505, in Baldwin, "Gates Pure," 29.

Fig. 10. Rembrandt, Christ Baptised in the Jordan, in Rachleff, 36.

Fig. 11. Rembrandt, Satan Showing Christ the Kingdom, in Rachleff, 39.

Fig. 12. Rembrandt, Abraham Dismissing Hagar, in Benesch, Fig. 656. 
Fig. 13. Rembrandt, Tobias Healing His Father's Blindness, in Held, Fig. 26.

Fig. 14. Rembrandt, Lucretia, paintings, in Bredius, Figs. 484, 485.

Fig. 15. Rembrandt, Lucretia, sketch, in Benesch, Fig. 136.

Fig. 16. Rembrandt, Lamentation, in Benesch, Fig. 117.

Fig. 17. Rembrandt, Manoah's Offering, in Benesch, Fig. 210

Fig. 18. Rembrandt, The Angel Departs from Manoah and His Wife, in Benesch, Fig. 209.

Fig. 19. Rembrandt, Tobias and 'Azarius' Walking, detail, in Held, Fig. 10.

Fig. 20. Rembrandt, Abraham and the Angel, in Benesch, Fig. 158.

Fig. 21. Rembrandt, The Angel Appearing to Hagar and Ismael in the Wilderness, in Bevers, Fig. 32.

Fig. 22. Rembrandt, The Angel Appearing to Elijah in the Desert, in Benesch, Fig. 1182.

Fig. 23. Rembrandt, The Angel and Saint Peter, in Benesch, Fig. 735.

Fig. 24. Rembrandt, The Angel Appears to Manoah, in Benesch, Fig. 94.

Fig. 25. Rembrandt, Christ on the Mt. of Olives, in Benesch, Figs. $122,151,180$.

Fig. 26. Rembrandt, Agony in the Garden, in Clark, 140. 
Devotional Zeal and Mystical "Humanation" in Rembrandt's Annunciation Sketch

Fig. 27. Rembrandt, Jacob Wrestling with an Angel, painting, in Halewood, Fig. 61.

Fig. 28. Rembrandt, Abraham's Sacrifice of Issac, etching, in Halewood, Fig. 62.

Fig. 29. Rembrandt, Abraham's Sacrifice, in Benesch, Fig. 105.

Fig. 30. Rembrandt, One of the Magi Kneeling Before the Virgin and Child, in Benesch, Fig. 135.

Fig. 31. Rembrandt, Healing of the Paralyzed Man, in Benesch, Fig. 130.

Fig. 32. Rembrandt, Adam and Eve, in Benesch, Fig. 194.

Fig. 33. Leaf from a Sienese Gradual, Annunciation in Letter V, ca. 1470, in Gottlieb, 127.

Fig. 34. Lorenzo Lotto, The Annunciation, ca.1527, in Gottlieb, 324.

Fig. 35. Fra Angelico, Cortona Annunciation, fresco, c. 1433, Museo del Prado, Madrid.

Fig. 36. Fra Filippo Lippi, Annunciation. c. 1435, National Gallery, Washington. 


\section{Bibliography}

Ackley, Clifford S. Rembrandt's Journey, Painter Draftsman, Etcher. Boston: MFA Publications, 2003.

Alpers, Svetlana. Rembrandt's Enterprise. Chicago: University of Chicago Press, 1985.

Bal, Mieke. Reading Rembrandt: Beyond the Word-Image Opposition. Cambridge: Cambridge University Press, 1991.

Baldinucci, Filippo. "Life of Rembrandt," from Cominciamento e Progresso dell'arte d'intagliare in rame colle vita de' piu eccellenti maestri della stessa professione. 1686, in ed. Charles Ford. Lives of Rembrandt. London: Pallas Athene, 2007, 35-48.

Baldwin, Robert. 'Gates Pure and Shining and Serene’: Mutual Gazing as an Amatory Motif in Western Literature and Art', in Eisenbichler, Konrad and Philip Sohm, "The Language of Gesture in the Renaissance, Selected proceedings of the conference held in Toronto, November 1983," Renaissance and Reformation. Vol. X, No. 1, 1986, 23-48.

Baldwin, Robert. "A Window from the Song of Songs in Conjugal Portraits by Fra Filippo Lippi and Bartholomaus Zeitblom," Source: Notes in the History of Art. Vol. 5(2), 1986, 7-14.

Baldwin, Robert. "Marriage as a Sacramental Reflection of Christ's Passion: The Mirror in Jan van Eyck's Arnolfini Wedding," Oud Holland. 98.2, 1984, 57-75. http://dx.doi.org/10.1163/187501784x00018

Benesch, Otto. The Drawings of Rembrandt: First Complete Edition in Six Volumes. Vol. I, London: Phaidon, 1973.

Bevers, H., L. Hendrix, W. Robinson, and P. Schatborn. Drawings by Rembrandt and his Pupils. Telling the Difference. LA: Getty Museum, 2009. 
Bevers, Holm, Peter Schatborn, and Barbara Welzel. Rembrandt: the Master and his Workshop. (Vol. II, Drawings and Etchings), London and New Haven: Yale University Press, 1991.

Blickle, Peter. "Social Protest and Reformation Theology," in Blickle, Peter, H. Rublack, and W. Schulze. Religion, Politics and Social Protest. London: George Allan and Unwin Publishers Ltd., 1984.

Bredius, A. The Paintings of Rembrandt. Vienna: Phaidon, 1937.

Bynum, Caroline Walker. Fragmentation and Redemption. Essays on Gender and the Human Body in Medieval Religion. New York: Zone Books, 1992.

Clarke, Kenneth. An Introduction to Rembrandt. London: John Murray, 1978.

Denny, Don. The Annunciation from the Right from Early Christian Times to the Sixteenth Century. New York and London: Garland Publishing, Inc., 1977.

Dickey, Stephanie S. "Mennonite Martyrdom in Amsterdam and the Art of Rembrandt and His Contemporaries," Proceedings of the American Association of Netherlandic Studies. Vol. 9, 1996, 81-103.

Goodman, Anthony and Angus MacKay. The Impact of Humanism on Western Europe. London: Longman, 1990. http://dx.doi.org/10.4324/9781315836225

Gottlieb, Carla. The Window in Art. New York: Abaris Books, 1981.

Haak, Bob. Rembrandt, His Life, His Work, and Times. London: Thames and Hudson, 1969.

Halewood, William H. Six Subjects of Reformation Art: A Preface to Rembrandt. Toronto: University of Toronto Press, 1982. 
Haverkamp-Begemann, Egbert. "Rembrandt," Encyclopedia of World Art. London and Toronto: McGraw-Hill Book Co. Vol. XI, 916-940.

Held, Julius S. Rembrandt and the Book of Tobit. Northampton, Mass: Gehenna Press, 1964.

Houbraken, Arnold. De Groote Schouburgh der Nederlantsche Konstchilders en Schilderessen. 3 Volumes. (Amsterdam, 17181721)

Hurll, Estelle M. Rembrandt, A Collection of Fifteen Pictures and a Portrait of the Painter with Introduction and Interpretation. Cambridge: The Riverside Press, 1899.

Kaufman, Peter I. Augustinian Piety and Catholic Reform. Macon, GA: Mercer University Press, 1982.

Koerner, Joseph. "Rembrandt and the Epiphany of the Face," Source: Notes in History of Art. Vol. 12, 1986, 5-32.

Landsberger, Franz. Rembrandt, the Jews, and the Bible. Trans. Felix Gerson. Philadelphia: the Jewish Publication Society of America, 1946.

Liedtke, W., C. Logan, N. M. Orenstein, and S. S. Dickey. Rembrandt / Not Rembrandt, in the Metropolitan Museum of Art. Vol. II, New York: Harry N. Abrams Inc., 1995.

Manuth, Volker. "Denomination and Iconography: the Choice of Subject Matter in the Biblical Paintings of the Rembrandt Circle." Simiolus. Vol. 22, No. 4, 1993-94, 235-52. http://dx.doi.org/10.2307/3780814

McLaughlin, R. Emmet. "Luther, Spiritualism and the Spirit," in eds. Steven Ozment, Marc R. Forster, and Benjamin J. Kaplan. Piety and Family in Early Modern Europe. Aldershot, UK: Ashgate Publishing Ltd., 2005, 28-49. 
Nadler, Steven. Rembrandt's Jews. London and Chicago: Chicago University Press, 2003.

Oberman, Heiko. "The Virgin Mary in Evangelical Perspective," The Impact of the Reformation. Grand Rapids, MI: William B. Eerdmans Publishing Co., 1994, 225-252.

Oberman, Heiko. “The Meaning of Mysticism from Meister Eckhart to Martin Luther," The Reformation: Roots and Ramifications. Grand Rapids, MI: William B. Eerdmans Publishing Co., 1994, 77-90.

Ozment, Steven. The Age of Reform, 1250-1550, An Intellectual and Religious History of Late Medieval and Reformation Europe. New Haven: Yale University Press, 1980.

Ozment, Steven. Mysticism and Dissent: Religious Ideology and Social Protest in the Sixteenth Century. New Haven: Yale University Press, 1973.

Packull, Werner O. Mysticism and the Early South German-Austrian Anabaptist Movement. (Studies in Anabaptist and Mennonite History, No. 19), Kitchener, Ont.: Herald Press, 1977.

Perlove, Shelley Karen. "Visual Exegesis: The Calvinist Context for Rembrandt's Etchings of the Life of Abraham," Impressions of Faith, Rembrandt's Biblical Etchings. Dearborn: University of Michigan-Dearborn, 1989, 11-23.

Pfurtner, Stephen. Luther and Aquinas on Salvation. trans. Edward Quinn, New York: Sheed and Ward, 1964.

Rachleff, Owen S. Rembrandt's Life of Christ. New York: Abradale Press, 1966.

Reardon, Bernard M.G. Religious Thought in the Reformation. Harlow: Longman, 1995. 
Schapelhouman, Marijn. Rembrandt and the Art of Drawing. Amsterdam: Rijksmuseum, and Zwolle: Waanders Publishers, 2006.

Scheper, George. The Spiritual Marriage: The Exegetical History and Literary Impact of the Song of Songs on the Middle Ages. Princeton: Princeton University Press, 1971.

Schwartz, Gary. "Man and God," Rembrandt's Universe. His Art, His Life, His World. London: Thames and Hudson, 2006, 315373.

Slive, Seymour. "Religious Subjects," Rembrandt Drawings. Los Angeles: The J. Paul Getty Museum, 2009, 195-219.

Slive, Seymour. Drawings of Rembrandt. New York: Dover, 1965.

Slive, Seymour. "Filippo Baldinucci," Rembrandt and His Critics. The Hague: M. Nijhoff, 1953, 104-115. http:/dx.doi.org/10.1007/978-94-015-0838-4

Slive, Seymour. "Realism and Symbolism in Seventeenth-Century Dutch Painting," Daedalus. 91, 1962, 469-500.

Smith, David R. “Towards a Protestant Aesthetics: Rembrandt's 1655 'Sacrifice of Isaac,' Art History. Vol. 8, No. 3, September 1985, 290-302. http://dx.doi.org/10.1111/j.1467-8365.1985.tb00169.x

Tumpel, Christian, and Astrid Tumpel. "Rembrandt's Commission from Prince Frederick Hendrick," Rembrandt: Images and Metaphors. trans. A. Bader and I. Bader. London: Haus Publishing, 2006, 92-103.

Vissert't Hooft, Willem. Rembrandt and the Gospel. London: Som Press, 1957.

Wencelius, Léon. "Réalité Rembrantienne et Grace Générale Calvinienne, "Calvin et Rembrandt. Paris: Société d'édition "Les Belles Lettres", 1937, 65-73. 
Devotional Zeal and Mystical "Humanation" in Rembrandt's Annunciation Sketch

Wetering, Ernst van de. "The Question of Authenticity: an Anachronism?" in ed. G. Cavalli-Bjorkman. Rembrandt and His Pupils. Papers Given at a Symposium in the Nationalmuseum Stockholm, 1992. Stockholm, 1993, 9-13.

Wetering, Ernst van de, ed. A Corpus of Rembrandt Paintings: Stichting Foundation Rembrandt Research Project. Vols.1-5, The Hague: Nijhoff, 1982.

Wheelock, Arthur. Rembrandt's Late Religious Portraits. Washington: National Gallery of Art, 2005.

White, Christopher. Rembrandt. London: Thames and Hudson, 1984.

Zumthor, Paul. Daily Life in Rembrandt's Holland. London:

Weidenfeld and Nicolson, 1959. 